\title{
Oral Lesions Associated with Post-COVID-19: Disease Sequels or Secondary Infection?
}

\author{
Lesiones Orales Post COVID-19: ¿Secuelas de la Enfermedad o Infección Secundaria?
}

\author{
Yuri de Lima Medeiros ${ }^{1}$ \& Letícia Drumond de Abreu Guimarães ${ }^{2}$
}

MEDEIROS, Y. L. \& GUIMARÃES, L. D. A. Oral lesions associated with post-COVID-19: Disease sequels or secondary infection? Int. J. Odontostomat., 15(4):812-816, 2021.

\begin{abstract}
The aim of this study was to report the presentation of oral lesions found in a post-COVID-19 patient. A 78-year-old female patient fifteen days post-COVID-19, confirmed through the PCR test, had pain in the mouth with a Visual Analogue Scale (VAS) 8, dysgeusia and odynophagia. Erosive lesions were observed with circumscribed halos, of different sizes along the entire length of the dorsum, bilateral margins of the tongue and labial mucosa. Topical use of vitamin $\mathrm{E} 40$ mg, nystatin oral suspension $100000 \mathrm{UI}$ and artificial saliva spray was prescribed. After 14 days, complete repair was observed. However, the patient worsened her respiratory failure and died after 2 days. There is still insufficient evidence to confirm whether this patient's oral lesion is the result of a direct viral infection with SARS-CoV-2. The relevance of inserting the dentist in the care team for infected patients stands out and we encourage the performance of intraoral evaluation, even after medical discharge. In this way, it will be possible to understand its long-term oral manifestations of COVID-19.
\end{abstract}

KEY WORDS: COVID-19, SARS-CoV-2, oral lesions, immunosuppression, intensive care unit.

\section{INTRODUCTION}

Corona virus disease (COVID-19) is caused by a novel coronavirus SARS-CoV-2, started in China and was declared a pandemic by the World Health Organization (Tu et al., 2020). Currently, the disease has spread to 188 countries, with more than 162 million reported cases and over 3.3 million deaths (World Health Organization, 2021). The lung is the main target organ and the manifestations are characterized by fever, dyspnea, dry cough, tiredness and diarrhea. With the increase in cases, new extra pulmonary clinical signs have been reported, such as gastrointestinal, cardiovascular, cutaneous, hematological and maxillofacial signs (Thakur et al., 2021).

Among the maxillofacial manifestations, taste dysfunctions are the most common, present in $45 \%$ of patients (Dos Santos et al., 2021) Although, recent studies have suggested that oral lesions could be a possible manifestation associated with COVID19. These lesions were quite heterogeneous, varying in their location and clinical aspects (Halboub et al., 2020; Gomes et al., 2021; Dos Santos et al.). Its pathogenesis and etiology is still questionable. Interestingly, other study showed that these lesions may be related from treatment of COVID-19 or immunosuppression (Guerrero, 2021; Pérez-Sayáns et al., 2021). The aim of this study was to report the presentation of oral lesions found in a post-COVID-19 patient.

\section{CASE REPORT}

A 78-year-old female patient fifteen days postCOVID-19, confirmed through the PCR test, had pain in the mouth with a Visual Analogue Scale (VAS) 8 , dysgeusia and odynophagia. The patient was lucid, with a regular systemic state, using $\mathrm{O} 26 \mathrm{UI}$ and $88 \%$ saturation. Erosive lesions were observed with

\footnotetext{
${ }^{1}$ School of Dentistry, Federal University of Juiz de Fora, Juiz de Fora, Minas Gerais, Brazil.

2 Department of Stomatology, University of São Paulo, São Paulo, Brazil.
} 
circumscribed halos, of different sizes along the entire length of the dorsum, bilateral margins of the tongue and labial mucosa (Figs. 1A-D). Some of these coalesced, forming a single lesion. The hypotheses of secondary infection fromtreatment, such as herpes simplex or candidiasis, or benign migratory glossitis after COVID-19 have been suggested. Biopsy was not performed due to the patient's weakened condition.

Topical use of vitamin E $40 \mathrm{mg}$, nystatin oral suspension $100000 \mathrm{UI}$, acyclovir (Zovirax ${ }^{\circledR} 250 \mathrm{mg}$ ) and artificial saliva spray (Dry mouth) was prescribed. After 1 day, it was observed that the circumscribed halos became more evident (Figs. 1E-H). The follow-up was maintained, it was observed that the areas started the repair (Figs. 1I-L). Clinical improvement was noted through progressive epithelialization of the lesion (Figs. $2 \mathrm{~A}-\mathrm{P}$ ) and pain, VAS 2. After 14 days, complete repair was observed (Figs. 2Q-T). However, the patient worsened her respiratory failure and died after 2 days.

\section{DISCUSSION}

The most common oral manifestations found in the literature were ulcers, vesiculobullous lesions, erythematous and white plaques. Among the locations, the dorsum tongue, hard palate and labial mucosa were the most affected sites (Halboub et al.; Iranmanesh et al., 2020; Gomes et al.). Fidan et al. (2021) analyzed 74 patients with COVID-19 and observed that $78.3 \%$ had an oral lesion. Iranmanesh et al. noted that $68 \%$ of these cases were symptomatic. Although, no study has investigated post-COVID-19 and follow up (Iranmanesh et al.).

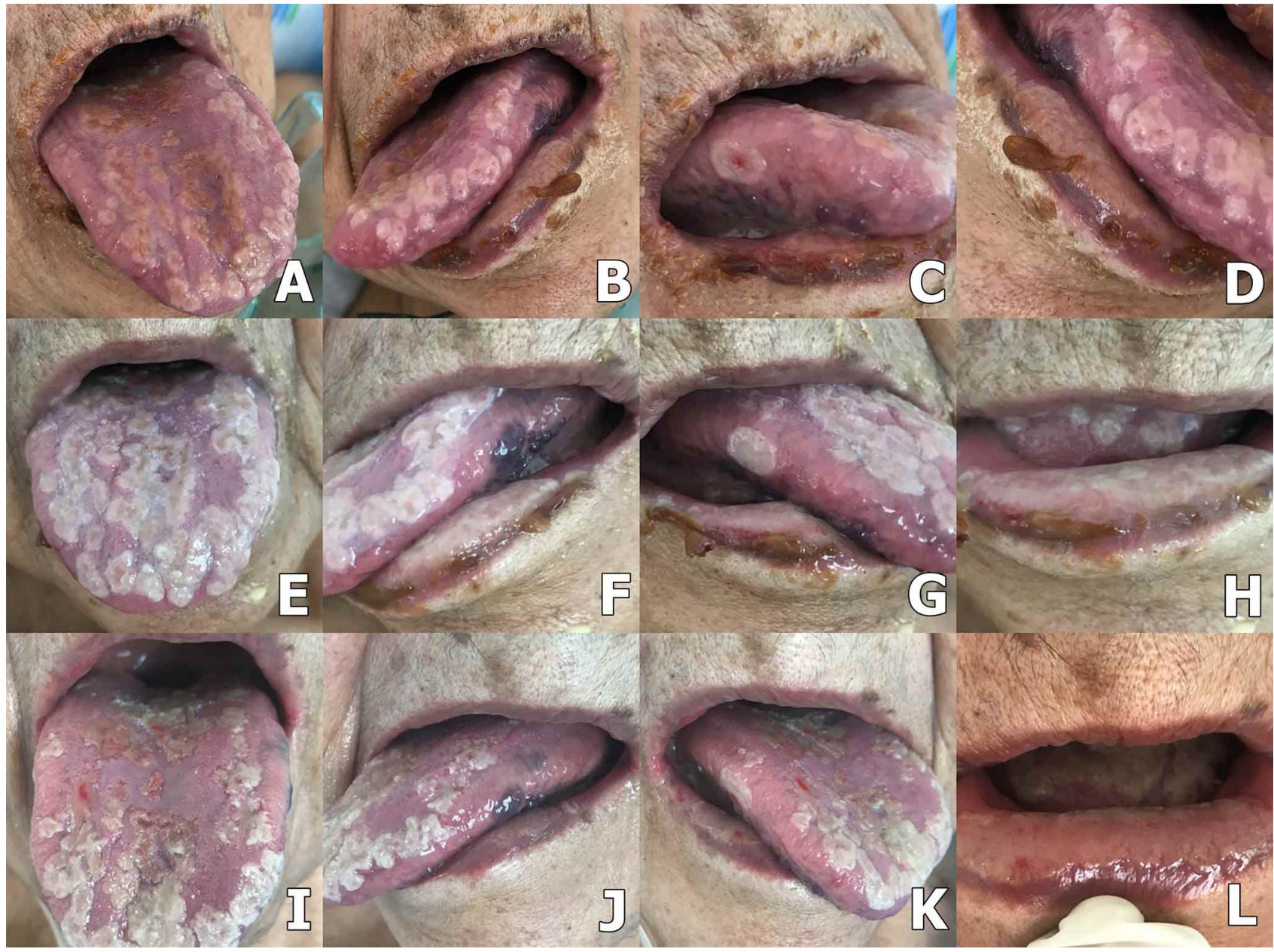

Fig. 1. A-D. Initial aspect of the condition showed erosive lesions with circumscribed halos, of different sizes along the entire length of the dorsum, bilateral margins of the tongue and labial mucosa. $(\mathrm{E}-\mathrm{H})$ After one day from topic treatment, it was observed that the circumscribed halos became thicker and whiter. (I-L) Progressive tissue epithelization of the lesion, during the third day of treatment. 


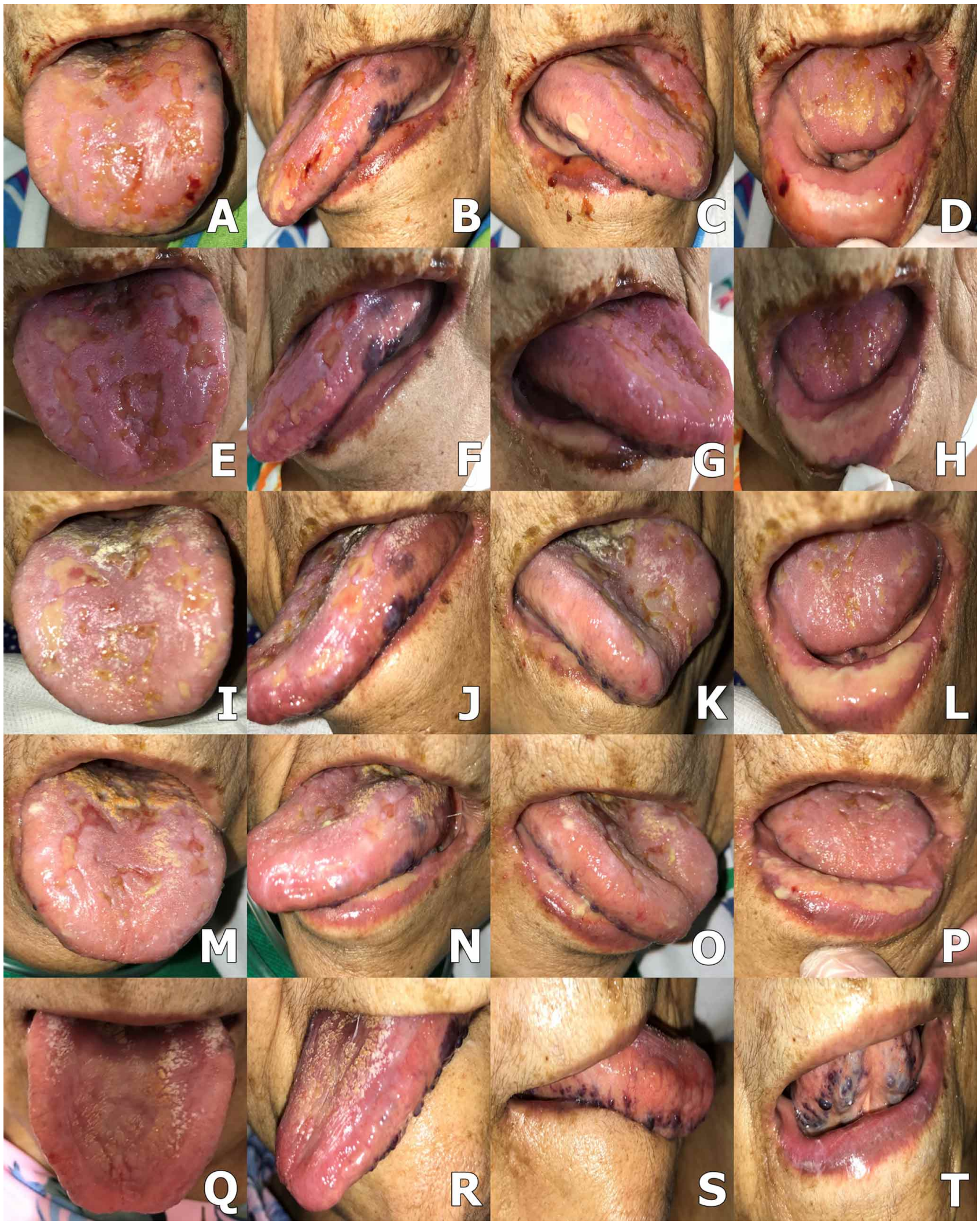

Fig. 2. Progressive tissue epithelization of the lesion, during the (A-D) fifth, $(E-H)$ seventh, $(I-L)$ tenth, $(M-P)$ twelfth and (QT) fourteenth day of treatment. 
With the interaction between SARS-CoV-2 and angiotensin-converting enzyme 2 (ACE2) receptors, there is an increase in cell wall permeability long-term, which could interrupt the function of oral keratinocytes, resulting in ulcers, erosion and necrosis (Brandão et al., 2021). In addition, these lesions could be justified by the variable systemic inflammatory reaction, which can induce inflammation and vascular complications, with primary or secondary changes to vascularhematological damage, as seen in cutaneous manifestations (Brandão et al.; Dos Santos et al.). They can also be related to another type of secondary infection, as herpes simplex and candidiasis, as well as being caused by xerostomia or secondary to the use of drugs to treat COVID-19 (Pérez-Sayáns et al.).

Therefore, these manifestations are probably secondary manifestation post treatment or due to the systemic deterioration caused by the disease. Therapeutic modalities used for COVID-19 infection, may contribute to oral health-related problems, as a result of an impaired immune system and susceptible mucosa (Halboub et al.; Bezerra et al., 2020; PérezSayáns et al.). Stress, due to social restrictions, can also play an important role in the appearance of these conditions (Petrescu et al., 2020).

\section{CONCLUSION}

For this reason, the relevance of involvement of the dentist in the care team for infected patients stands out and we encourage the performance of intraoral evaluation, even after medical discharge and follow up. In this way, it will be possible to understand its longterm oral manifestations post-COVID-19.

MEDEIROS, Y. L. \& GUIMARÃES, L. D. A. Lesiones orales post COVID-19: ¿secuelas de la enfermedad o infección secundaria? Int. J. Odontostomat., 15(4):812-816, 2021.

RESUMEN: El objetivo de este estudio fue reportar las lesiones orales encontradas en un paciente post-COVID19. Paciente de sexo femenino de 78 años, con quince días post-COVID-19, confirmada mediante prueba de PCR, el cual presentaba dolor en la cavidad oral con una Escala Visual Analógica (EVA) 8, disgeusia y odinofagia. Se observaron lesiones erosivas con halos circunscritos, de diferentes tamaños a lo largo de todo el dorso, márgenes bilaterales de la lengua y mucosa labial. Se prescribió el uso tópico de vitamina E $40 \mathrm{mg}$, nistatina suspensión oral $100000 \mathrm{UI}$ y spray de saliva artificial. Después de 14 días, se observó una reparación completa. Sin embargo, la paciente empeo- ró su insuficiencia respiratoria y falleció a los 2 días. Aún no hay evidencia suficiente para confirmar si la lesión oral de este paciente es el resultado de una infección viral directa con SARS-CoV-2. Destaca la relevancia de la inserción del odontólogo en el equipo de atención del paciente infectado y fomentamos la realización de la evaluación intraoral, incluso después del alta médica. De esta manera, será posible comprender sus manifestaciones orales a largo plazo de COVID-19.

PALABRAS CLAVE: COVID-19, SARS-CoV-2, lesiones orales, inmunosupresión, unidad de cuidados intensivos.

\section{REFERENCES}

Bezerra, T. M.; Feitosa, S. G.; Carneiro, D. T. O.; Costa, F. W. G.; Pires, F. R. \& Pereira, K. M. A. Oral lesions in COVID-19 infection: Is long-term follow-up important in the affected patients? Oral Dis, 2020. DOI: https://www.doi.org/10.1111/odi.13705

Brandão, T. B.; Gueiros, L. A.; Melo, T. S.; Prado-Ribeiro, A. C. Nesrallah, A. C. F. A.; Prado, G. V. B.; Santos-Silva, A. R. \& 6 Migliorati, C. A. Oral lesions in patients with SARS-CoV-2 infection: could the oral cavity be a target organ? Oral Surg. Oral Med. Oral Pathol. Oral Radiol., 131(2):45-51, 2021.

Dos Santos, J. A.; Normando, A. G. C.; da Silva, R. L. C.; Acevedo, A. C.; De Luca Canto, G.; Sugaya, N.; Santos-Silva, A. R. \& Guerra, E. N. S. Oral manifestations in patients with COVID-19: a living systematic review. J. Dent. Res., 100(2):141-54, 2021.

Fidan, V.; Koyuncu, H. \& Akin, O. Oral lesions in Covid 19 positive patients. Am. J. Otolaryngol., 42(3):102905, 2021.

Gomes, A. C.; Ferreira, D. S.; Silva, M. M.; Barros, C. C. S.; Menezes, N. S. \& Santos, H. B. P. Oral alterations in a COVID-19 patient: case report and update of main findings. Int. J. Odontostomat., 15(2):315-9, 2021.

Guerrero, D. Y. Oral manifestations related to COVID-19. Int. J. Odontostomat, 15(2):307-8, 2021.

Halboub, E.; Al-Maweri, S. A.; Alanazi, R. H.; Qaid, N. M. \& Abdulrab, S. Orofacial manifestations of COVID-19: a brief review of the published literature. Braz. Oral Res., 34:e124, 2020.

Iranmanesh, B.; Khalili, M.; Amiri, R.; Zartab, H. \& Aflatoonian, M. Oral manifestations of COVID-19 disease: A review article. Dermatol. Ther., 34(1):e14578, 2020.

Pérez-Sayáns, M.; Ortega, K. L.; Braz-Silva, P. H.; Carreras-Presas, C. M. \& Carrión, A. B. Can "COVID-19 tongue" be considered a pathognomonic finding in SARS-CoV-2 infection? Oral Dis., 2021. DOI: https://www.doi.org/10.1111/odi.13807

Petrescu, N.; Lucaciu, O. \& Roman, A. Oral mucosa lesions in COVID-19. Oral Dis, 2020. DOI: https://www.doi.org/10.1111/ odi.13499

Thakur, V.; Ratho, R. K.; Kumar, P.; Bhatia, S. K.; Bora, I.; Mohi, G. K.; Saxena, S. K.; Devi, M.; Yadav, D. \& Mehariya, S. Multi-organ involvement in COVID-19: beyond pulmonary manifestations. J. Clin. Med., 10(3):446, 2021

Tu, H.; Tu, S.; Gao, S.; Shao, A. \& Sheng, J. Current epidemiological and clinical features of COVID-19; a global perspective from China. J. Infect., 81(1):1-9, 2020.

World Health Organization (WHO). Weekly Operational Update on COVID-19. Geneve, World Health Organization, 2021. Available from: https://www.who.int/emergencies/diseases/novelcoronavirus-2019/situation-reports/ 
MEDEIROS, Y. L. \& GUIMARÃES, L. D. A. Lesiones orales post COVID-19: ¿secuelas de la enfermedad o infección secundaria? Int. J. Odontostomat., 15(4):812-816, 2021.

Corresponding author:

Letícia Drumond de Abreu Guimarães

Av. Prof. Lineu Prestes, 2227

Butantã

São Paulo - SP, 05508-000

BRAZIL

E-mail: leticiadrumond@usp.br

Yuri de Lima Medeiros

orcid.org/0000-0002-4013-7752

Letícia Drumond de Abreu Guimarães

orcid.org/0000-0002-5015-8506 